\title{
Efficacy of Ocimum gratissimum essential oil against the monogenean Cichlidogyrus tilapiae gill parasite of Nile tilapia
}

[Eficácia do óleo essencial de Ocimum gratissimum contra o monogenea Cichlidogyrus tilapiae parasita de brânquias de tilápia-do-nilo]

\author{
J.O. Meneses ${ }^{1}$, M.V.S. do Couto ${ }^{2}$, N.C. Sousa ${ }^{2}$, F. dos S. Cunha ${ }^{1}$, H.A. Abe ${ }^{2}$, F.M. Ramos ${ }^{3}$, E.C. Chagas $^{4}$, \\ F.C.M. Chaves $^{4}$, M.L. Martins ${ }^{5}$, A.N. Maria ${ }^{6}$, P.C F. Carneiro ${ }^{6}$, R.Y. Fujimoto ${ }^{6 *}$ \\ ${ }^{1}$ Universidade Tiradentes - Aracaju, SE \\ ${ }^{2}$ Universidade Federal do Pará - UFPA - Belém, PA \\ ${ }^{3}$ Instituto Federal do Pará - IFPA - Cametá, PA \\ ${ }^{4}$ Embrapa Amazônia Oriental - Manaus, AM \\ ${ }^{5}$ AQUOS - Universidade Federal de Santa Catarina - UFSC - Florianópolis, SC \\ ${ }^{6}$ Embrapa Tabuleiros Costeiros - Aracaju, SE
}

\begin{abstract}
The phythotherapy is an alternative to use of chemotherapeutical agents against monogenean infection. This study evaluated the anthelmintic activity of essential oil Ocimum gratissimum against monogenean Cichlidogyrus tilapiae as well as its acute toxicity in tilapia juveniles. The mean lethal concentration $\left(\mathrm{LC}_{50}\right)$ and different concentrations of the essential oil, both in vitro and in vivo assays (short and longterm baths) were assessed. The $\mathrm{LC}_{50}$ was $40.70 \mathrm{mg} . \mathrm{L}^{-1}$ and in the in vitro assay this concentration showed $80 \%$ efficacy at the last two hours and in the in vivo assay $65.87 \%$ efficacy in long-term bath. However, it provoked morphological alterations on the gills such as hyperplasia and edema. The parasites exposure at the highest concentration $\left(320 \mathrm{mg}^{-\mathrm{L}^{-1}}\right.$ ) showed $100 \%$ mortality after $2 \mathrm{~h}$ exposure in the in vitro assay, whereas in the in vivo assay, short-term baths of $5 \mathrm{~min}$ for 3 consecutive days showed an efficacy of $87.71 \%$ without gills damage. These results demonstrate the anthelminthic activity of essential oil $O$. gratissimum and the safety concentration to use in Nile tilapia.
\end{abstract}

Keywords: disease, freshwater fish, helminth, natural product, treatment

\section{RESUMO}

A fitoterapia é uma alternativa ao uso de agentes químicos contra infecções por parasitos monogenéticos. Este estudo avaliou a atividade anti-helmíntica do óleo essencial Ocimum gratissimum contra o monogenea Cichlidogyrus tilapiae, bem como sua toxicidade aguda e histopatologia em juvenis de tilápias. Foram avaliadas a concentração letal média $\left(C L_{50}\right)$ e diferentes concentrações de óleo essencial, tanto in vitro como in vivo (banho de curta e longa duração). A $C_{50}$ foi de 40,70mg. $L^{-1}$; no ensaio in vitro, essa concentração apresentou $80 \%$ de eficácia, e no ensaio in vivo 65,87\% de eficácia em banho de exposição crônica. No entanto, provocou alterações morfológicas nas brânquias, como hiperplasia e edema. A exposição dos parasitas na concentração mais elevada (320mg. ${ }^{-1}$ ) mostrou $100 \%$ de mortalidade após duas horas de exposição no ensaio in vitro, enquanto no ensaio in vivo, em banho de curta duração de cinco minutos, durante três dias consecutivos, apresentou uma eficácia de $87,71 \%$, sem danos às brânquias. Esses resultados demonstraram a atividade anti-helmíntica do óleo essencial de O. gratissimum e a concentração de segurança para uso na tilápia-do-nilo em banhos de curta duração.

Palavras-chave: doença, peixe de água doce, helmintos, produto natural, tratamento

Recebido em 2 de fevereiro de 2016

Aceito em 20 de abril de 2017

* Autor para correspondência (corresponding author)

Email: rodrigo.fujimoto@embrapa.br 


\section{INTRODUCTION}

Outbreak of diseases in production facilities can cause expressive financial losses to fish farmers (Faruk et al., 2004), among these diseases, the monogenean helminths are the main cause of mortalities (Martins et al., 2002; Pinto et al., 2009) being considered an obstacle to productivity of fish farms in intensive systems.

Over the past years, the use of medicinal plants in aquaculture for diseases control has been prioritized because of its high therapeutic potential since observed to fishes and shrimps in several countries, such as Mexico (Ocampo and Jimenez, 1993), India (Chakraborty and Hancz, 2011), Thailand (Direkbusarakom et al., 1996) and Brazil (Hashimoto et al., 2016). Furthermore, the use of medicinal plants can avoid the use of chemotherapeutic agents which provoke resistant parasites and impacts on the environment (Doughari et al., 2009).

The extracts and essential oil of plants have been used in controlling fish monogeneans, such as the Artemisia annua extract against the monogenean in Heterobranchus longifilis (Ekanem and Brisibe, 2010), tea tree essential oils against Gyrodactylus sp. in Gasterosteus aculeatus (Steverding et al., 2005), cinnamon oil against monogenean in tambaqui Colossoma macropomum (Boijink et al., 2015), Mentha piperita and Lippia sidoides essential oil against Cichlidogyrus tilapiae, C. thurstonae, C. halli, and Scutogyrus longicornis gill parasites of Nile tilapia Oreochromis niloticus (Hashimoto et al., 2016) and Cajeput (Melaleuca cajuputi) oil against Gyrodactylus turnbulli of guppies (Poecilia reticulata) (Schelkle et al., 2015).

Ocimum gratissimum commonly known as African basil, is widely distributed in tropical regions, and has the eugenol as the main compound presenting analgesic, antimicrobial, antifungal and immunostimulant activity (Silva et al., 2012). The use of $O$. gratissimum leaf extracts or essential oil presented efficacy against Haemonchus contortus, helminth parasite from small ruminants (Pessoa et al., 2002). However, its efficacy for monogenean parasites and toxicity for Nile tilapia has not been proven.

The current study evaluated the anthelmintic activity of $O$. gratissimum essential oil against
Cichlidogyrus tilapiae as well as its acute toxicity and histopathological effect on Nile tilapia juveniles.

\section{MATERIAL AND METHODS}

This study was approved by the Embrapa Ethics Committee for Animal Experimentation (CEUA/02.12.01.020.00.06.006/2014).

Tilapia (Oreochromis niloticus) originated from a local fish farmer were transported to Embrapa Tabuleiros Costeiros Aquaculture Laboratory, acclimatized in polyethylene tanks (500L) and maintained for 10 days at $26.2 \pm 0.81^{\circ} \mathrm{C}$ (YSI model 55-12FT), dissolved oxygen $6.45 \pm 0.58 \mathrm{mg} . \mathrm{L}^{-1}$ (YSI model 55-12FT), $\mathrm{pH}$ $7.33 \pm 0.7$ (AKROM model KR20) and total ammonia $0.55 \pm 0.07 \mathrm{mg} . \mathrm{L}^{-1}$ (HANNA model HI 93715) in recirculation system with artificial aeration. Extruded diet for omnivore fish $(28 \%$ crude protein) was offered twice a day. Additionally three experimental assays were carried out: acute toxicity (mean lethal concentration, $\mathrm{LC}_{50}$ ) to evaluate the toxic effects on tilapia juveniles, in vitro and in vivo assays to evaluate the efficacy of concentrations and strategies of application against monogenean.

The herbal Ocimum gratissimum was cultured in EMBRAPA Western Amazon, Manaus, AM, Brazil (10 $56^{\prime} 45.7^{\prime \prime} \mathrm{S}$ and $\left.37^{\circ} 02^{\prime} 58.5^{\prime \prime} \mathrm{W}\right)$ and the shoots of one year old and reproductive stages were collected for extraction by hydro distillation using Clevenger-like equipment. The leaves $(100 \mathrm{~g})$ were added to a flask (2L) with $1000 \mathrm{~mL}$ distilled water. The essential oil samples were quantified and stored at a temperature of $-20^{\circ} \mathrm{C}$. After extraction, the essential oil showed $42.3 \%$ of eugenol, $20.4 \%$ of 1.8 cineole (eucalyptol) and $12.9 \%$ of $\beta$-selinene as major chemical components determined by gas chromatography according to Potzernheim et al. (2012) (Table 1). Prior to assays, the oil samples were diluted in $70 \%$ alcohol $(1: 10 \mathrm{v}: \mathrm{v})$ and maintained refrigerated at $-18^{\circ} \mathrm{C}$ (Inoue et al., 2005).

The methodology used to determine the mean lethal concentration was based on protocols defined by the US Environmental Protection Agency (EPA, 1996). The experiment used 72 tilapias (O. niloticus) $(2.99 \mathrm{~g}$ weight and $6.4 \mathrm{~cm}$ total length) distributed into 18 recipients. The 
recipients consisted of beakers containing $2 \mathrm{~L}$ of water and fish biomass of $11.97 \pm 1.75 \mathrm{~g}$. The experiment was carried out in a static system, lasted $96 \mathrm{~h}$, evaluating six concentrations of the essential oil $\left(0,20,40,60,80\right.$ and $\left.100 \mathrm{mg} . \mathrm{L}^{-1}\right)$ in triplicate. The mortality and behavior was evaluated every $6 \mathrm{~h}$ with removal of the dead fish.

Table 1. Chemical compounds of essential oil of clove basil

\begin{tabular}{ccc}
\hline RI & Identification & Proportion (\%) \\
\hline 932 & $\alpha$-pinene & 1.4 \\
972 & sabinene & 0.8 \\
976 & $\beta$-pinene & 3.8 \\
1027 & Limonene & 0.7 \\
1029 & 1,8 -cineole & 20.4 \\
1100 & Linalool & 1.6 \\
1165 & $\delta$-terpineol & 0.6 \\
1190 & $\alpha$-terpineol & 1.6 \\
1357 & Eugenol & 42.3 \\
1418 & $($ E)-caryophyllene & 4.9 \\
1450 & $\alpha$-humulene & 0.8 \\
1488 & $\beta$-selinene & 12.9 \\
1494 & $\alpha$-selineno & 3.2 \\
1513 & BHT & 1.0 \\
1582 & Caryophyllene oxide & 4.0 \\
\hline
\end{tabular}

The monogeneans ( $C$. tilapiae) were collected from the gill arches from 10 fish (30-50g weight). The fish were euthanatized by medullar section. An essential oil solution was prepared with $650 \mu 1$ of $O$. gratissimum oil and $350 \mu 1$ of $70 \%$ alcohol (Inoue et al., 2005). The in vitro assay was carried out with 5 treatments in triplicate each as follows: control; control plus $70 \%$ alcohol and parasites exposed at concentrations of 40,160 and $320 \mathrm{mg} . \mathrm{L}^{-1}$ of essential oil. The monogeneans $(n=75)$ were transferred to Petri dishes and mortalities were observed every hour for five hour aided by stereomicroscope (Hashimoto et al., 2016). The monogenean were considered dead if they did not show any movement, even after tactile stimulation (Sutili et al., 2014) and when it transferred to water without the oil.

The bests results from in vitro assay (160 and 320mg. $\mathrm{L}^{-1}$ ), the mean lethal concentration
$\left(\mathrm{LC}_{50}=40 \mathrm{mg} \cdot \mathrm{L}^{-1}\right)$ and $9 \mathrm{mg} . \mathrm{L}^{-1}$ of essential oil were used to evaluated the short and long-term therapeutic baths. Seventy five tilapia (mean weight $61.27 \pm 25.81 \mathrm{~g}$; mean total length $14.63 \pm 2.06 \mathrm{~cm})$ were distributed in 15 tanks (90L, static system and constant aeration). The experiment was carried out with 5 treatments (control; 9mg.L $\mathrm{L}^{-1}$; 40mg.L $\mathrm{L}^{-1} ; 160 \mathrm{mg} . \mathrm{L}^{-1}$ and $320 \mathrm{mg} . \mathrm{L}^{-1}$ essential oil) in triplicate.

The concentrations of $9 \mathrm{mg} . \mathrm{L}^{-1}$ and $40 \mathrm{mg} . \mathrm{L}^{-1}$ were applied as long-term baths lasted $48 \mathrm{~h}$ by dilution of essential oil in the fish tanks. Further, the concentrations of $160 \mathrm{mg} . \mathrm{L}^{-1}$ and $320 \mathrm{mg} . \mathrm{L}^{-1}$ were applied as short-term baths of 10 and $5 \mathrm{~min}$, respectively, for three consecutive days. For the last two concentrations, the fish were removed from tanks and immersed on the concentrations of essential oil in recipients of 5L capacity. After the time exposure, the fish were reallocated in original tanks.

At the end of experimental period all fish were euthanized by medullar sectioning and their gills were collected and fixed in $10 \%$ neutral buffered formalin. The gill arches were submitted to histological analysis (Behmer et al., 1976) and sections of $5 \mu \mathrm{m}$ were stained with hematoxylineosin (H\&E). The lesions were evaluated semiquantitatively by ranking tissue lesion according to the severity as suggested by Sirimongkolvorakul et al. (2012).

Other fragments were analyzed in Petri dishes for monogenean quantification using a stereomicroscope. Parasite indices of prevalence and mean intensity (Bush et al., 1997), the total number of parasites, survival rates and the efficacy of the therapeutic baths (Martins et al., 2001) were determined.

The normality and homogeneity of variances were analyzed by Shapiro Wilk and Bartlett tests, respectively. Data without normality distribution was transformed in arcsen (survival, total of parasites, prevalence, mean intensity, efficacy) and submitted to Analysis of Variance (ANOVA) and Tukey tests $(\mathrm{P}<0.05)$ (Zar, 1999). The lethal concentration $\left(\mathrm{CL}_{50} ; 96 \mathrm{~h}\right)$ was determined by using the Trimmed Spearman Karber method (Hamilton et al., 1977). 


\section{RESULTS}

The lethal concentration $\left(\mathrm{LC}_{50} ; 96 \mathrm{~h}\right)$ of $O$. gratissimum oil for Nile tilapia was $40.70 \mathrm{mg} . \mathrm{L}^{-1}$ with the highest and the lowest limits of $51.44 \mathrm{mg} . \mathrm{L}^{-1}$ and $32.20 \mathrm{mg} . \mathrm{L}^{-1}$, respectively. In the highest concentration, $83.3 \%$ mortality was found after $6 \mathrm{~h}$ exposure. At the end of experimental period, the mortality rates were $33.33 \%, 50 \%, 75 \%, 83.33 \%$ and $100 \%$ at the concentrations of 20, 40, 60, 80 and 100mg.. ${ }^{-1}$, respectively. Fish exposed to higher concentrations of $O$. gratissimum essential oil showed an equilibrium loss and reduced opercular movement.
During the first hour of exposure a monogenean mortality of $87 \%$ was observed in concentration of $320 \mathrm{mg} . \mathrm{L}^{-1}$ achieving a total mortality at the second hour. The concentration of $160 \mathrm{mg} . \mathrm{L}^{-1}$ provoked $33 \%, 87 \%$ and $100 \%$ mortality after the first, second and third hour, respectively. The concentration of $40 \mathrm{mg} . \mathrm{L}^{-1}$ showed $80 \%$ monogenean mortality during the last two hours. Nevertheless, no difference between controls and treatments was found after $2 \mathrm{~h} \quad(\mathrm{P}<0.05)$ (Figure 1).

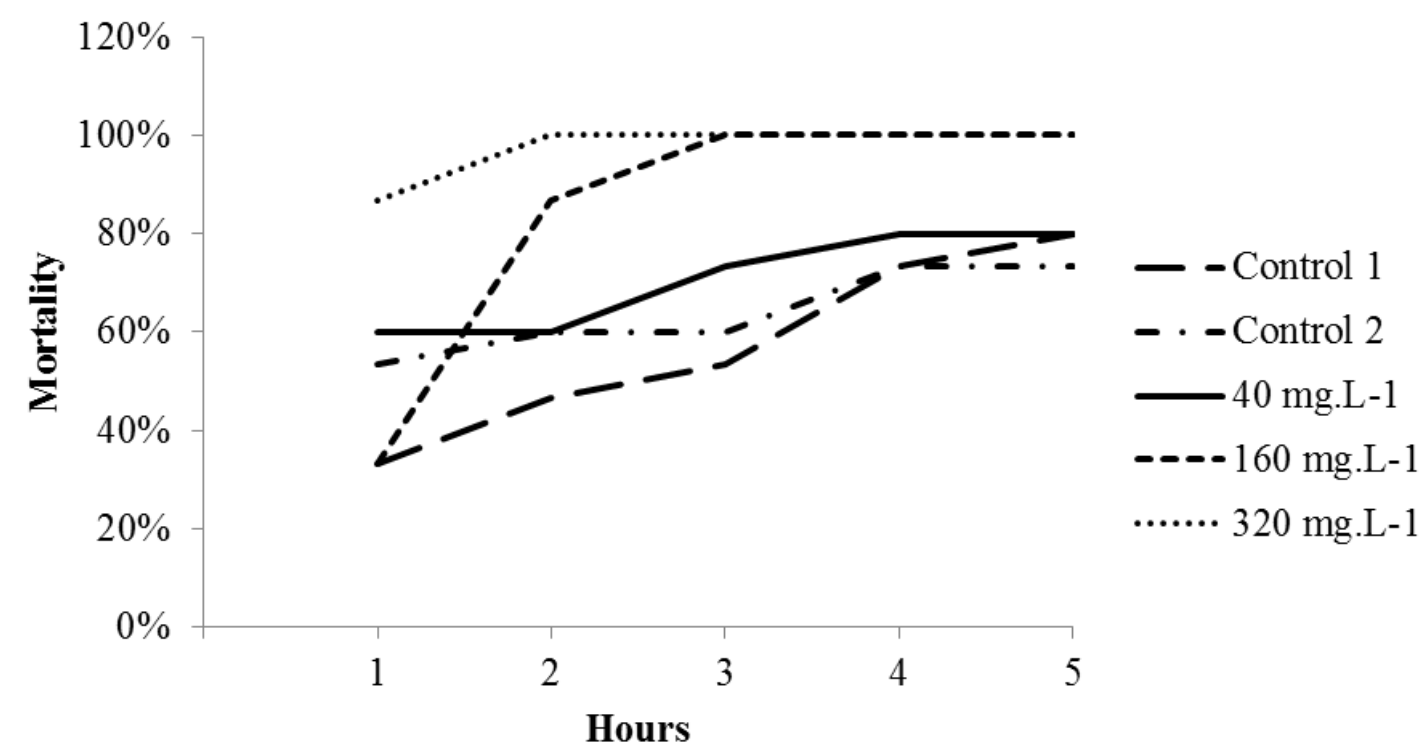

Figure 1. Monogenean mortality (\%) after exposure at different concentrations of Ocimum gratissimum essential oil.*Difference by Tukey test $(\mathrm{P}<0.05)$.

Tilapia survival did not differ between the groups exposed to the essential oil and control (Figure 2A). However, anesthetic effects were observed in fish exposed to higher concentrations of $O$. gratissimum reflected by equilibrium loss and reduction of opercular movement.

Regarding parasite control, there was no significant difference $(\mathrm{P}>0.05)$ in prevalence among the treatments (Figure 2B). Nevertheless, significant difference $(\mathrm{P}<0.05)$ in the mean intensities was observed. The highest values for mean intensity were observed in control and the lowest value in the highest concentrations 160 and $320 \mathrm{mg} . \mathrm{L}^{-1}$ (Figure 2C). Fish exposure at $160 \mathrm{mg} . \mathrm{L}^{-1}$ and $320 \mathrm{mg} . \mathrm{L}^{-1}$ presented efficacy of $86.68 \%$ and $87.71 \% \quad(\mathrm{P}<0.05)$, respectively (Figure 2D). The long-term baths $\left(9 \mathrm{mg} . \mathrm{L}^{-1}\right.$ and $40 \mathrm{mg} . \mathrm{L}^{-1}$ ) presented a light reduction of parasitic infection with efficacy of $52.90 \%$ and $65.87 \%$, respectively (Figure 2D), however, no difference was observed in the mean intensity.

Morphologically, the long-term baths (9 and 40mg. $\mathrm{L}^{-1}$ ) caused hyperplasia on branchial epithelial cells of primary lamellae and epithelium lifting in the secondary lamellae with sub-epithelial edema (Figure 3, Table 2). 

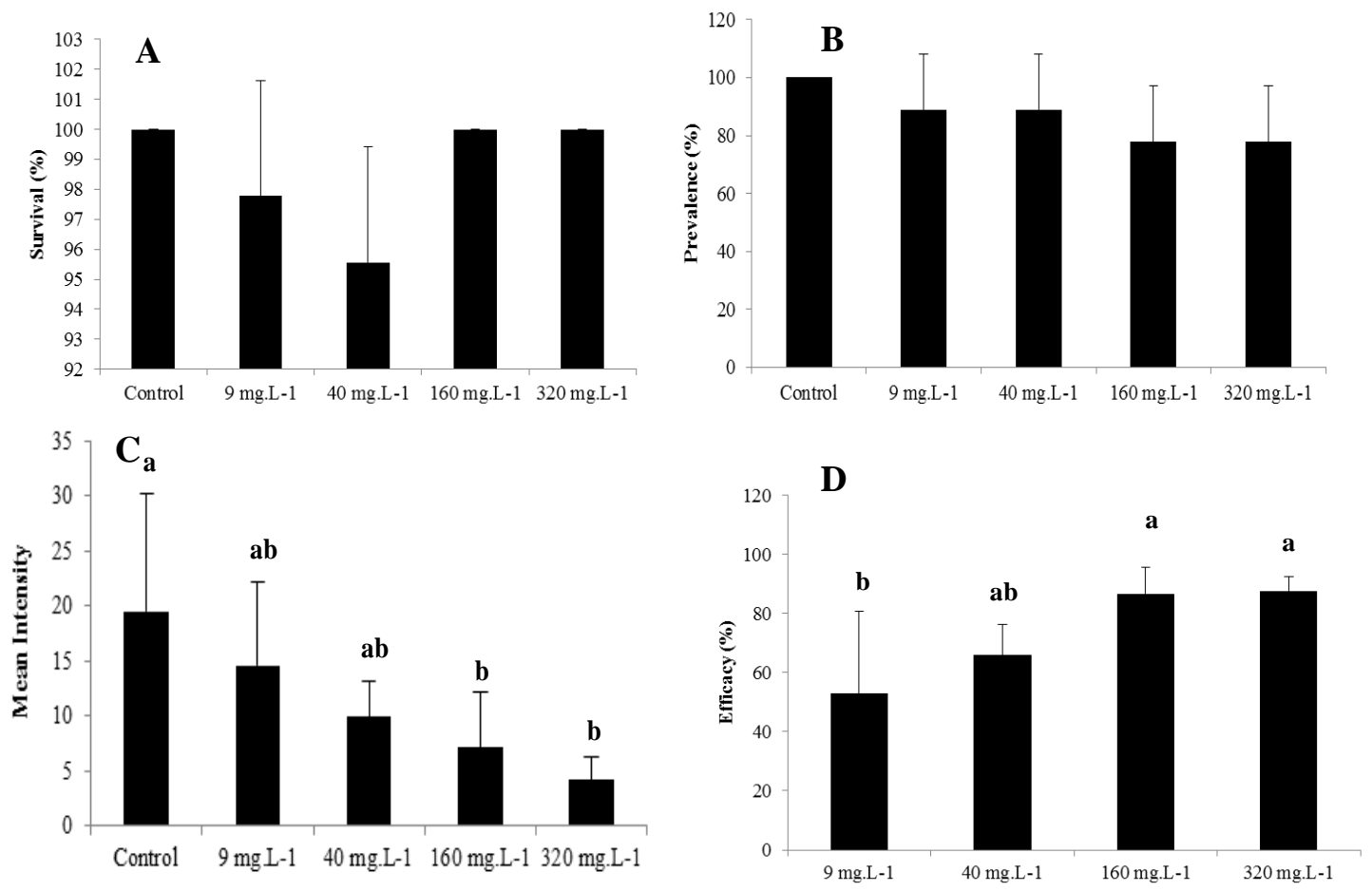

Figure 2. (A) Survival of fish after exposure at different concentrations of $O$. gratissimum essential oil. (B) Prevalence of monogenean. (C) Mean intensity of monogenean. (D) Efficacy against monogenean. Mean values ( \pm $\mathrm{SD})$ with the same letter did not differ statistically by Tukey test $(\mathrm{P}>0.05)$.

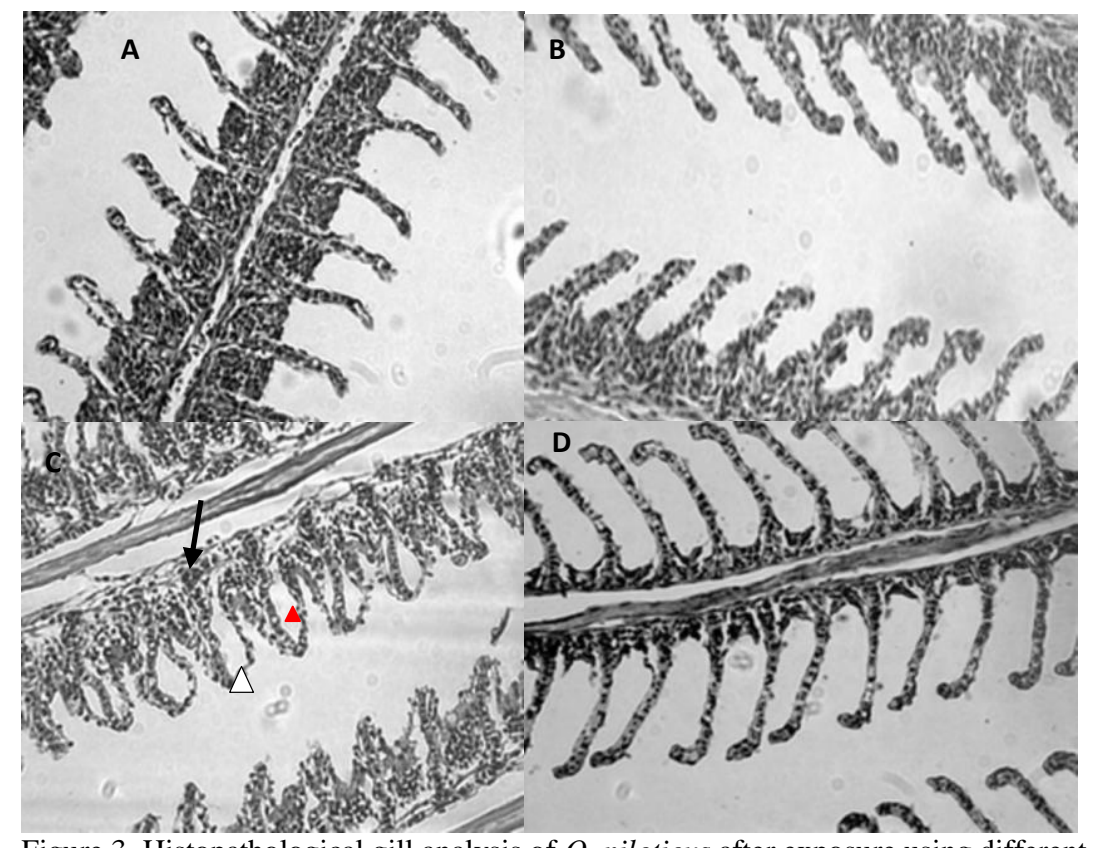

Figure 3. Histopathological gill analysis of $O$. niloticus after exposure using different concentration and application methods of $O$. gratissimum oil. (A) Control group: normal appearance of gills showing light hyperplasia. (B) Group exposure in long-term baths with $9 \mathrm{mg} . \mathrm{L}^{-1}$ : gills displaying severe hyperplasia. (C) Group exposure in long-term baths with 40mg. $\mathrm{L}^{-1}$ : gills displaying severe hyperplasia (arrow) and epithelial lifting and subepithelial edema (arrow head). (D) Group exposures in short-term baths with 160 and $320 \mathrm{mg} \cdot \mathrm{L}^{-1}$ : gills showing normal appearance. Note: $\mathrm{H} \& \mathrm{E}$ stain and 40X. 
Table 2. Histopathological gill analysis of Oreochromis niloticus after exposure using different concentrations and application methods of Ocimum gratissimum oil

\begin{tabular}{cccccc} 
Alterations & Control & $9 \mathrm{mg} \cdot \mathrm{L}^{-1}$ & $40 \mathrm{mg} \cdot \mathrm{L}^{-1}$ & $160 \mathrm{mg} \cdot \mathrm{L}^{-1}$ & $320 \mathrm{mgL}^{-1}$ \\
\hline $\begin{array}{c}\text { Primary filament } \\
\text { hyperplasia } \\
\text { Epithelial lifting }\end{array}$ & + & ++ & +++ & - & - \\
\hline
\end{tabular}

(-) no histopathology; (+) histopathology in more than $20 \%$ of the fields; (++) histopathology in 20 to $60 \%$ of fields and $(+++)$ histopathology in more than $60 \%$ of the fields.

\section{DISCUSSION}

Studies on $O$. gratissimum toxicity in fish are scarce. Crude leaves extract from this plant present $\mathrm{LC}_{50}$ of $1.271,22 \mathrm{mg} . \mathrm{L}^{-1}$ for fish (Kone et al., 2013) higher value than that found in present study. In fact, lower concentrations of essential oil provoked similar effect, which demonstrates the higher toxicity of the essential oil compared to extract.

Eugenol, the major compound of the $O$. gratissimum essential oil (Silva et al., 2012), was found to be $\mathrm{LC}_{50}$ of $71.68 \mathrm{mg} . \mathrm{L}^{-1}$ (Pratte-Santos and Carrielo, 2010), 184.26mg.L $\mathrm{L}^{-1}$ (Vidal et al., 2008) for tilapia larvae $(0.44 \mathrm{~g})$ and fingerlings $(5.34 \mathrm{~g})$, respectively. The $O$. gratissimum essential oil was more toxic for tilapia than eugenol, demonstrating that other compounds of essential oil can affect the toxicity for fish. However, for the other two major components, 1.8 cineole and $\beta$-selinene, no information on the toxicity for fish is available.

The anthelminthic activity of essential oil of $O$. gratissimum was also observed in monogenean of tambaqui (Colossoma macropomum) at 10 and $15 \mathrm{mg} . \mathrm{L}^{-1}$ after one week of exposure (Boijink et al., 2016). The authors assigned the anthelminthic effect to the eugenol, the main compound of $O$. gratissimum essential oil. An anthelminthic activity has also been reported for 1.8 cineole (Oliveira et al., 2014) the second major compound of $O$. gratissimum essential oil. Furthermore, the $\beta$-selinene is present in the essential oil of many plants and it was the third major compound of $O$. gratissimum oil, but no anthelminthic activity has been reported.

The eugenol presented efficacies of 80 and $90 \%$ against monogenean Gyrodactylus sp., parasite of jundiá (Rhamdia quelen), when exposured to 5 and $10 \mathrm{mg} . \mathrm{L}^{-1}$ for $1 \mathrm{~h}$ baths (Sutili et al., 2014). Compared to $O$. gratissimum oil, similar efficacies were observed in therapeutic shortterm baths at 160 and $320 \mathrm{mg} \mathrm{L}^{-1}$ for 10 and 5 minutes, respectively. These concentrations presented higher values of eugenol equivalent concentrations of $67.2 \mathrm{mg} . \mathrm{L}^{-1}$ and $134.4 \mathrm{mg} . \mathrm{L}^{-1}$, respectively.

In long-term baths (48h), lower efficacies of $52.90 \%$ and $65.87 \%$ were observed at concentrations of $9 \mathrm{mg} . \mathrm{L}^{-1}$ (3.6mg. $\mathrm{L}^{-1}$ eugenol equivalent) and $40 \mathrm{mg} . \mathrm{L}^{-1}$ of essential oil (16.8mg.L $\mathrm{L}^{-1}$ eugenol equivalent), respectively. The lower efficacy values in long-term baths is probably due to a toxicological antagonism effect among eugenol and 1.8 cineole. However, this hypothesis remains to be proven. Moreover, the sensitivity of monogenean is species-specific and concentration and exposure time affect the efficacy of the treatments (Boijink et al., 2016) and the fish survival.

Higher concentrations as $300 \mathrm{mg} . \mathrm{L}^{-1}$ could be utilized in short-term baths (4min) to anesthetize without physiological damage or fish mortalities (Silva et al., 2012). The short-term therapeutic baths (5 and 10min) with 160 and $320 \mathrm{mg}^{-1} \mathrm{~L}^{-1}$ of O. gratissimum oil presented the best results of efficacy without morphological gill damage.

The hyperplasia and edema found in long-term baths are common responses to pollutant and metal contaminations representing an adaptive response to maintain physiological functions of fish (Sirimongkolvorakul et al., 2012). Concentrations above $30 \mathrm{mg} . \mathrm{L}^{-1}$ of essential oil of O. gratissimum for long period cause fish mortalities (Silva et al., 2012) as observed in treatment with 9 and $40 \mathrm{mg} \cdot \mathrm{L}^{-1}$. These long-term baths with essential oil aggravated the 
morphological damage and probably fish more sensitive died due to those alterations.

An anesthetic effect of essential oil of $O$. gratissimum were reported to tambaqui ( $C$. macropomum) and matrinxã (Brycon amazonicus) at concentrations of $50-100 \mathrm{mg} . \mathrm{L}^{-1}$ for 10min (Boijink et al., 2016). No stress was reported in tilapia exposed to eugenol until 80mg.L $\mathrm{L}^{-1}$ (Deriggi et al., 2006). Therefore, a strategic measure of the essential oil of $O$. gratissimum combining the anesthetic and parasite control effects must be considered as a prophylactic method and would be an interesting measure benefiting the animal welfare.

\section{CONCLUSION}

The essential oil of $O$. gratissimum can be safely used as anthelmintic against gill monogenean Cichlidogyrus tilapiae when applied $160 \mathrm{mg} . \mathrm{L}^{-1}$ in short term baths (10min).

\section{ACNOWLEDGMENTS}

Santa Clara Fish Farm - Sergipe; José Júlio dos Santos ("Seu Tenente") - producer; Fish Farm Station of Itiúba (CODEVASF) and National Council for Scientific and Technological Development $(\mathrm{CNPq})$ for financial support to $\mathrm{R}$. Y. Fujimoto (305195/2016-6) and M.L. Martins (305869/2014-0).

\section{REFERENCES}

BEHMER, O.A.; TOLOSA, E.M.C.; FREITAS NETO, A.G. Manual de técnicas para histologia normal e patológica. São Paulo: EDART, 1976. $456 \mathrm{p}$.

BOIJINK, C.L.; MIRANDA, W.S.C.; CHAGAS, E.C. Anthelmintic activity of eugenol in tambaquis with monogenean gill infection. Aquaculture, v.438, p.138-140, 2015.

BOIJINK, C.L.; QUEIROZ, C.A.; CHAGAS, E.C. et al. Anesthetic and anthelminthic effects of clove basil (Ocimum gratissimum) essential oil for Tambaqui (Colossoma macropomum). Aquaculture, v.457, p.24-28, 2016.

BUSH, A.O.; LAFFERTTY, K.D.; LOTZ, J.M.; SHOSTAK, A.W. Parasitology meets ecology on its own terms: Margolis et al. revisited. J. Parasitol., v.83, p.575-583, 1997.
CHAKRABORTY, S.B.; HANCZ, C. Application of phytochemicals as immunostimulant antipathogenic and antistress agents in finfish culture. Rev. Aquacult., v.3, p.103-119, 2011.

DERIGGI, G.F.; INOUE, L.A.K.A.; MORAES, G. Stress responses to handling in Nile Tilapia (Oreochromis niloticus Linnaeus): assessment of eugenol as an alternative anesthetic. Acta Sci. Biol. Sci., v.28, p.269-274, 2006.

DIREKBUSARAKOM, S.; HERUNSALEE, A.; YOSHIMIZU, M.; EZURA, Y. Antiviral activity of several Thai traditional herb extracts against pathogenic viruses. Fish Pathol., v.31, p.209213, 1996.

DOUGHARI, J.H.; HUMAN, I.S.; BENNADE, S.; NDAKIDEMI, P.A. Phytochemicals as chemotherapeutic agents and antioxidants: possible solution to the control of antibiotic resistant verocytotoxin producing bacteria. $J$. Med. Plants Res., v.3, p.839-848, 2009.

ENVIRONMENTAL PROTECTION AGENCY (USEPA). Ecological effects test guidelines OPPTS 8501075. Fish acute toxicity test freshwater and Marine. [Washington]: EPA, 1996. 11p.

EKANEM, A.P.; BRISIBE, E.A. Effects of ethanol extract of Artemisia annua L against monogenean parasites of Heterobranchus longifilis. Parasitol. Res., v.106, p.1135-1139, 2010.

FARUK, M.A.R.; SARKER, M.M.R.; ALAM, M.J.; KABIR, M.B. Economic loss from fish diseases on rural freshwater aquaculture in Bangladesh. Pak. J. Biol. Sci., v.7, p.2086-2091, 2004.

HAMILTON, M.A.; RUSSO, R.C.; THURSTON, V. Trimmed Spearman-Karber method for estimating medial lethal concentrations in toxicity bioassays. Environ. Sci. Technol., v.11, p.714-719, 1977.

HASHIMOTO, G.S.O.; NETO, F.M.; RUIZ, M.L. et al. Essential oils of Lippia sidoides and Mentha piperita against monogenean parasites and their influence on the hematology of Nile tilapia. Aquaculture, v.450, p.182-186, 2016. 
INOUE, L.A.K.A.; AFONSO, L.O.B.; IWAMA, G.K.; MORAES, G. Effects of clove oil on stress responses of matrinxa subjected to transport. Acta Amazonica, v.35, p.289-295, 2005.

KONE, M.; CISSE, M.; AFFOURMOU, K. et al. In vivo antiparasitic effects of an African's traditional plant Ocimum gratissimum (Linneaus 1758) on fish louse Argulus spp. infesting the Nile tilapia males Oreochromis niloticus (Linneaus 1758) in fish farming. Open Sci. Repository Vet. Med., online (open-access), e23050447, 2013.

MARTINS, M.L.; MORAES, J.R.E.; ANDRADE, P.M. et al. Piscinoodinium pillulare (Schaperclaus 1954) Lom 1981 (Dinoflagellida) infection in cultivated freshwater fish from the northeast region of São Paulo State Brazil. Parasitological and pathological aspects. Braz. J. Biol., v.61, p.639-644, 2001.

MARTINS, M.L.; ONAKA, E.M.; MORAES, F.R. et al. Recent studies on parasitic infections of freshwater cultivated fish in the State of São Paulo Brazil. Acta Sci. Anim. Sci., v.24, p.981985, 2002.

OCAMPO, A.A.; JIMENEZ, E.M. Herbal medicines in the treatment of fish diseases in Mexico. Vet. Mex., v.24, p.291-295, 1993.

OLIVEIRA, G.L.; VIEIRA, T.M.; NUNES, V.F. et al. Chemical composition and efficacy in the egg-hacthing inhibition of essential oil of Piper aduncum against Haemonchus contortus from sheep. Rev. Bras. Farmacogn., v.24, p.288-292, 2014.

PESSOA, L.M.; MORAIS, S.M.; BEVILAQUAA, C.M.L.; LUCIANO, J.H.S. Anthelmintic activity of essential oil of Ocimum gratissimum Linn and eugenol against Haemonchus contorts. Vet. Parasitol., v.109, p.59-63, 2002.

PINTO, E.; GARCIA, A.M.; FIGUEIREDO, H.C.P. et al. Primeiro relato de Tripartiella $\mathrm{sp}$ (Ciliophora: Peritrichia) em Pseudoplatystoma corruscans (Osteichthyes: Pimelodidae) cultivado no Estado de Mato Grosso do Sul Brasil com descrição de nova espécie. Bol. Inst. Pesca, v.35, p.91-97, 2009.
POTZERNHEIM, M.C.; BIZZO, H.R.; SILVA, J.P.; VIEIRA, R.F. Chemical characterization of essential oil constituents of four populations of Piper aduncum L. from Distrito Federal, Brazil. Biochem. Soc. Ecol., v.42, p.25-31, 2012.

PRATTE-SANTOS, R.; CARRIELO, F.A.D. Toxicidade aguda de eugenol em juvenis I de Tilápia (Oreochromis niloticus). Rev. Cient. Faminas, v.5, p.95-104, 2010.

SCHELKLE, B.; SNELLGROVE, D.; JONES, L.L.; CABLE, J. Efficacy of commercially available products against Gyrodactylus turnbulli infections on guppies Poecilia reticulata. Dis. Aquat. Org., v.115, p.129-137, 2015.

SILVA, L.L.; PARODI, T.V.; RECKZIEGEL, P. et al. Essential oil of Ocimum gratissimum L: anesthetic effects mechanism of action and tolerance in silver catfish Rhamdia quelen. Aquaculture, v.350, p.91-97, 2012.

SIRIMONGKOLVORAKUL, S.; TANSATIT, T.; PREYAVICHYAPUGDEE, N. et al. Efficiency of Moringa oleifera dietary supplement reducing lead toxicity in Puntius altus. J. Med. Plants Res., v.6, p.187-194, 2012.

STEVERDING, D.; MORGAN, E.; TKACZYNSKI, P. et al. Effect of Australian tea tree oil on Gyrodactylus spp infection of the three-spined stickleback Gasterosteus aculeatus. Dis. Aquat. Org. v.66, p.29-32, 2005.

SUTILI, F.J.; GRESSLER, L.T.; BALDISSEROTTO, B. Anthelmintic activity of the phytochemical eugenol against the fish parasite Gyrodactylus sp and acute toxicity in Daphnia pulex. Panam. J. Aquat. Sci., v.9, p.223-22, 2014.

VIDAL, L.V.O; ALBINATI, R.C.B.; ALBINATI, A.C.L. et al. Eugenol como anestésico para a tilápia-do-Nilo. Pesqui. Agropecu. Bras., v.43, p.1069-1074, 2008.

ZAR, J.H. Biostatistical analysis. New Jersey: Prentice-Hall, 1999. 663p. 